\title{
South Africa's business process outsourcing services sector: Lessons for Western-based client firms
}

\author{
M.C. Lacity ${ }^{\mathrm{a} *}$, L.P. Willcocks ${ }^{\mathrm{b}}$ and A. Craig ${ }^{\mathrm{c}}$ \\ ${ }^{a}$ College of Business, University of Missouri-St. Louis, One University Boulevard, St. Louis, MO 63121 \\ ${ }^{b}$ Department of Management, Information Systems and Innovation Group, London School of Economics and Political Science, Houghton \\ Street, London WC2A $2 \mathrm{AE}$ \\ The Outsourcing Unit, London School of Economics and Political Science, Houghton Street, London WC2A $2 \mathrm{AE}$ \\ *To whom all correspondence should be addressed \\ Mary.Lacity@umsl.edu
}

\begin{abstract}
Since 2008, South Africa has become one of the world's upcoming offshore destinations for business process outsourcing (BPO), a market estimated to be worth \$US 182 billion globally by 2013. Western-based client firms evaluating South Africa as a BPO destination must consider the country's relative value against alternative locations. Client firms also have a number of engagement models from which to choose, including outsourcing, erecting a captive centre, or acquiring an existing $\mathrm{BPO}$ business. The research finds that, for the $\mathrm{UK}_{2} \mathrm{US}$, and Australian client companies in this study, South Africa's value proposition is not just based on costs as other locations are often cheaper. South Africa's value proposition is about overall economic value, high quality service and staff, strong cultural compatibility, and a favourable time zone. The findings reveal that South Africa complements the global portfolio for Western-based client firms that already have BPO centres in India, the Philippines, and Eastern Europe. Moreover, whether client firms build or buy services from South Africa, the research identifies distinctive risks that need to be mitigated by investing in and effectively governing the business processes performed offshore. Finally, from the case study research, this article identifies management lessons for leveraging South Africa's identifiable BPO service advantage.
\end{abstract}

\section{Introduction}

For this article, Western-based firms are defined as organisations based in Europe or in countries settled by Europeans, including Australia, Canada, and the United States. For the past two decades, Western-based firms have been the primary customers for the global Business Process Outsourcing (BPO) market, estimated to be worth \$US 182 billion globally (Harris, Hale, Brown, Young \& Morikawa, 2010). Western-based client firms have primarily chosen BPO providers based in the BRIC countries (representing Brazil, Russia, India, and China), but they increasingly wish to diversify their country-specific risks. Since 2008, South Africa has become one of the world's up and coming BPO offshore destinations. By 2012, South Africa won the National Outsourcing Association's (NOA) UK Offshoring Destination of the Year Award. In 2013, South Africa won the European Outsourcing Association's (EOA) Offshoring Destination of the Year Award (South Africa The Good News, 2013). The South African call centre industry, a subset of the BPO sector, has grown by approximately $8 \%$ per year since 2003, and it directly employs about 54000 people, contributing $0.92 \%$ to South Africa's gross domestic product (GDP) ${ }^{1}$. As an emerging BPO destination, Westernbased client firms evaluating South Africa must consider the country's relative value vis-à-vis alternative locations.

\footnotetext{
southafrica.info (2009) Outsourcing to South Africa, In Queue http:/www.southafrica.info/husiness/investing/opportunities/bpooverview.htm
}

Client firms also have a number of engagement models from which to choose, including captive centres, build-transferoperate (BOT), acquisitions, and outsourcing. Captive centers are wholly owned subsidiaries that provide business services to the parent company from an offshore location. Clients select a captive engagement model when they are concerned about the protection of intellectual property and when they seek a high level of control over offshore operations (Oshri, 2011). A BOT is a type of arrangement in which a client firm pays a BPO provider to build an offshore delivery center, hire and train employees, and operate it for a short period before transferring ownership to the client company. Clients select a BOT engagement model when they want to access a local provider's expertise in establishing what will eventually be a wholly owned captive center (Vashistha \& Vashistha, 2006). An acquisition occurs when a company acquires a third-party service provider. A client firm may acquire a third-party provider to expand quickly the client firm's capabilities. For example, Aetna and AIG both acquired offshore providers to build instantly offshore captive centers (Vashistha \& Vashistha, 2006). Outsourcing is when a client organisation contracts for business services from a third-party service provider (Lacity \& Willcocks 2012). Outsourcing is the only engagement model among these four that does not entail any client ownership.

The engagement models are not mutually exclusive; many large client firms use hybrid versions of these models, like captive centers that also sell their services to customers 
besides the parent company, or joint ventures (Oshri, 2011; Vashistha \& Vashistha, 2006). Many large companies, like General Electric and British Petroleum, use several or even all of these options (Lacity \& Willcocks, 2012; Hindle, Willcocks, Feeny, \& Lacity, 2003). Sourcing options also change over time; client firms may for example initially erect a captive centre, and then later sell it (Oshri, 2011; Oshri \& Van Uhm, 2012).

As evidenced by the NAO and EAO awards, many Westernbased client firms are choosing South Africa as a destination and leveraging South Africa's BPO service advantage through captive centres, acquisitions, and outsourcing. Major companies like Lufthansa, Amazon, ASDA, Shell, and T Mobile, for example, have set up captive centres in South Africa. Providers like Capita, Serco and WNS have acquired, or partnered with, local companies to steer their client work to South Africa's advantageous offering, and new outsourcing deals have been struck, for example Shop Direct-Serco-Teleperformance and iiNet-Merchants (Business Wire, 2011). Clearly, South Africa seeks to be a major player in the global BPO market, and Western-based client firms examining South Africa as a destination will wish to learn more from early entrants. Thus far, there is little-if any-empirical academic studies on the BPO service sector based in South Africa. $^{2}$ This research therefore sought answers to two questions:

1. Why do Western-based client firms select South Africa as a destination for BPO services?

2. Which management practices lead to successful sourcing outcomes in South Africa?

Although South Africa's BPO sector has not been studied specifically by academics, a large amount of prior BPO research can inform the research questions asked above.

\footnotetext{
${ }^{2}$ Whilst we cannot claim with certainty there are no empirical academic articles on BPO in South Africa, we did not find any in ABI inform and EBSCO. In $\mathrm{ABI}$ Inform, no peer-reviewed articles using the search terms "South Africa" and "BPO" in the abstract field were found on May 14, 2013. When the peer-reviewed search was broadened to include "South Africa" and "BPO" in any search field (not just the abstract), 63 articles appeared, but none of these were studies of BPO sector in South Africa. For example, Lanerolle, I. 2011. 'Convergence and Regulation in South Africa,' Communications Policy Research Africa Conference Proceedings, 13(3):47-63 has the words "South Africa" and "BPO" in the text, but the 18 page article has just one sentence on BPO: "For some years, the South African government has identified the Business Process Outsourcing (BPO) sector as a significant opportunity for driving economic growth and job creation" (p. 3). The rest of the article is about broadcasting and telecommunications regulations. In EBSCO, one peer-reviewed article was found when using the search terms "South Africa" and "BPO" in the abstract field. The article, titled "Outsourcing and Offshoring" appeared in a 2009 publication of the Africa Research Bulletin. (46) 11: p18503-18503. The one page article discusses. why Teff Smith, Teleperformance UK chairman, decided to expand their facilities in South Africa.
}

\section{Theories of outsourcing decisions and outcomes}

To study BPO phenomena, researchers have appropriated theories from many disciplines, including economics, strategy, and sociology. Theories from economics include Transaction Cost Economics (Coase, 1937; Williamson, 1975, 1991, 1996), Agency Theory (Eisenhardt,1985, 1989; Sharma, 1997), and various theories on contracting (Domberger, 1998; MacNeil, 1980). The main assumption across economic theories is that agents base outsourcing decisions and engage in contracts to minimize total costs and to mitigate risks, such as the risk that an agent or provider will behave opportunistically (Lacity \& Willcocks, 2009). Theories from strategy include the Resource-Based View (Barney, 1991, 1999), Resource Dependency Theory (Pfeffer \& Salancik, 1978; Pfeffer, 1981, 1994), and various theories of firm strategy (Miles \& Snow, 1978; Porter, 1985; Pralahad \& Hamel, 1990). The main assumption across strategic theories is that agents build or acquire resources to execute strategies that lead to "winning" (Lacity \& Willcocks, 2009). Theories from sociology include Social/Relational Exchange Theory (Ekeh, 1974; Rousseau, 1995, Social Capital Theory (Nahapiet \& Ghosal, 1998), Institutionalism (DiMaggio \& Powell 1991), Power Theories (Pfeffer 1981, 1994), and Innovation Diffusion (Rogers, 1983). A common focus among these theories is the relationships among agents, including levels of trust and power, feelings of mutual obligation, and social norms (Lacity \& Willcocks, 2009).

In reviewing empirical tests of these theories in the BPO context, Lacity, Solomon, Yan \& Willcocks (2011) coded 615 relationships between independent and dependent variables from 87 BPO articles published between 1996 and 2011 in 67 peer-reviewed journals. For the determinants of outsourcing decisions, which can help inform the first research question, the authors found repeated empirical support that client firms use BPO to reduce total costs (transaction and production costs) as predicted by Transaction Cost Economics (e.g., Saxena \& Bharadwaj, 2009), to focus on core capabilities as predicted by the Resource Based View (e.g., Mahmoodzadeh, Jalalinia, \& Yazdi, 2009) and to access provider skills and expertise as predicted by Resource Dependency Theory (e.g., Lam \& Chua, 2009). The authors found a negative relationship between the Critical Role of the Business Process and decisions to outsource, as predicted by theories from strategy (e.g., Sanders, Locke, Moore, \& Autry, 2007; Dobrzykowski, Tran, \& Tarafdar, 2010).

Theories of country attractiveness have also been used to study outsourcing decisions and also are particularly relevant to the first research question. A widely adopted theory of country competitiveness is based on three constructs: a country's business, financial, and human resource attractiveness (Malos, 2009; Doh, Bunyaratavej \& Hahn, 2009). A country's business attractiveness is the degree to which a country is attractive to organisations because of favourable business environmental factors such 
as economic stability, political stability, cultural compatibility, infrastructure quality, and security of intellectual property (IP) (e.g., Malos, 2009; Doh et al,. 2009). A country's financial attractiveness is the degree to which a country is attractive because of favourable financial factors such as labour costs, taxes, regulatory, and other costs (e.g., Malos 2009; Doh et al., 2009). A country's human resource attractiveness is the degree to which a country is attractive because of favourable people skills and availability factors such as size of labour pool, education, language skills, experience, and attrition rates (e.g., Malos 2009; Mehta, Armenakis, Mehta, \& Irani, 2006). As evidenced by situations such as the political upheavals in Egypt in $2011^{3}$ which halted international investment in Egypt's Information Technology Outsourcing (ITO) services export market, a country's attractiveness can change rapidly.

The BPO literature review also assessed if certain types of country characteristics affected BPO outcomes (Lacity et al., 2011). In this broad category, only one independent variable had been tested repeatedly, cultural distance. Cultural distance refers to the extent to which the members of two distinct groups (such as clients and providers) differ on one or more cultural dimensions. The greater the cultural distance, the less likely clients reported positive outcomes from BPO. Overall, cultural distance negatively affected BPO outcomes (e.g., Kim, 2008).

For the determinants of outsourcing outcomes, which can help inform the second research question, the empirical BPO review by Lacity et al., (2011) found a positive correlation between contractual governance and outcomes (e.g., Handley \& Benton 2009; Niranjan, Saxena, \& Bharadwaj, 2007; Wüllenweber, Beimborn, Weitzel, \& König, 2008) as predicted by Transaction Cost Economics and between relational governance and outcomes as predicted from sociology theories. In particular, higher values for all these relational governance variables were associated with better BPO outcomes: communication, effective knowledge sharing, partnership view (treating the provider as a trusted partner rather than as an opportunistic vendor) and relationship specific investments (e.g., Kim \& Kim, 2008; Mahmoodzadeh et al., 2009; Sen \& Shiel, 2006). Other important aspects of relational governance include protecting the partner's commercial interests, resolving conflicts collaboratively, and designing good governance structures (Kern, Willcocks \& Van Heck, 2002; Lacity \& Willcocks 2013).

Client firm and provider firm capabilities were also important determinants of BPO outcomes as predicted by theories from strategy (Lacity et al., 2011). Client firms were more likely to successfully outsource a business process that they could efficiently and effectively manage themselves (e.g., Saxena \& Bharadwaj, 2009). Clients must also develop the ability to manage BPO providers and to manage change during the transition and operation phases

\footnotetext{
3 "Egypt's crisis: where social media threatens global outsourcing," http://www horsesforsources.com/egypt-crisis-012911.
}

(e.g., Sanders et al, 2007; Lacity \& Willcöks 2012). For offshore outsourcing, additional client investments in knowledge sharing and coordination contribute to positive outcomes (Carmel \& Tjia, 2005; Dibbern, Winkler \& Heinzl, 2008; Lacity \& Rottman, 2008). The provider's human resource management capability was repeatedly identified as an important supplier capability, which is defined as the provider's ability to identify, acquire, develop, and deploy human resources to achieve both supplier's and client's organisational objectives (e.g., Borman, 2006).

In summary, best practices for making BPO decisions and for achieving good outcomes is largely known from prior theoretical and empirical BPO research. However-none of the 615 BPO relationships examined in Lacity et al, (2011) include examples of Western-based clients building on buying BPO services from South Africa. Because South Africa is an important and emerging, yet under-studied BPO destination, a case study method that is informed by prior BPO research is an appropriate research method. With case studies, prior practices can be assessed in a new context while still providing methodological flexibility for new constructs to emerge (Denzin \& Lincoln, 2000).

\section{Case study research method}

Case studies are a suitable method for answering how and why questions about contemporary events over which the researcher has little or no control (Fontana \& Frey, 1994; Yin, 2003). We sought to find representative cases of Western-based client firms that selected South Africa as a destination for BPO services using (a) outsourcing (i.e., contracting services from a BPO provider based in South Africa), (b) captive centre (i.e., erecting a BPO deliver center which is owned by the Western-based company), and (c) acquisition engagement models (a Western-based company purchases a BPO company based in South Africa).

The primary data collection method consisted of in-depth phone interviews with key informants. Interviewees are "key" in that they provide particularly important understandings of their collectivity because they have a particularly rich knowledge of the collectivity through their seniority or through their specialist roles in the setting (Bloor \& Wood, 2013; Parsons, 2013). Interviews with key informants are also appropriate for understanding the participant's own perspectives (Kvale, 1996; Klein \& Myers, 1999), when seeking participation from busy or high-status respondents and when seeking answers to questions in which the subject matter is sensitive (Mahoney, 1997).

Based on the prior BPO literature, we designed two semistructured interview schedules, one for the client key informants and one for provider/partner key informants. For client participants, the interview schedule consisted of openended questions extracted from previous BPO research discussed above on outsourcing strategy, country selection criteria, provider/partner selection, contractual governance, 
transition of work, ongoing delivery, relational governance, client and provider capabilities, decision outcomes, and overall lessons learned. The provider/partner interview schedule included the same set of questions, beginning with the provider's participation in the client firm's provider selection process. Research sponsors from Business Process Enabling South Africa (BPeSA) (see acknowledgements) reviewed the schedules for clarity and understandability.

With a key informant method, the sample size is less relevant than targeting participants with full knowledge of the phenomenon under study, in this case, leveraging South Africa's BPO service advantage (Creswell, 1998; Ponterotto \& Casas, 1991; Seidler, 1974). Key informants should be selected based on their knowledge of the issues and organisational position (Elmendorf \& Luloff, 2006). In total, this article is based on eleven key informant interviews. With the assistance of BPeSA, we selected eight key informants from four Western-based client firms to study: British Gas, iiNet, Amazon, and Capita. British Gas is a subsidiary of Centrica, a $£ 23$ billion British multinational utility company with over 20 million residential and commercial customers and 30,000 employees in the UK.
iiNet is Australia's second largest internet service provider with revenues of about a half billion Australian dollars and over 1.3 million customers. As the world's largest online retailer, US-based Amazon earned $\$ 48$ billion in revenue in 2011 and employed 69,000 people. Capita is the UK's largest BPO and professional services company with over $£ 3$ billion in annual turnover, delivering back office administration and front office customer contact services to private and public sector organisations based in the UK and Ireland. In addition, three experts on the BPO industry in South Africa were formally interviewed to get a better understanding of industry's strengths and weaknesses.

For each case study, key informants from the client firms responsible for the South African sourcing decision and provider executives in charge of delivery (as well as provider CEOs) were interviewed (see Table 1). Initial interviews lasted between 60 minutes and 75 minutes. All interviews were recorded and transcribed. The key informants also shared a large number of documents, including power point presentations, customer satisfaction surveys, and internal and external reports.

\section{Table 1: Key informant interview}

\begin{tabular}{|c|c|c|c|c|}
\hline Title & $\begin{array}{l}\text { Role in } \\
\text { Case study }\end{array}$ & Company & $\begin{array}{l}\text { Date of } \\
\text { Interview }\end{array}$ & Representing \\
\hline $\begin{array}{l}\text { General Manager for } \\
\text { British Gas (BG) } \\
\text { Residential }\end{array}$ & $\begin{array}{l}\text { Accountability for outsourcing, and relationships with } \\
\text { company's several million residential customers using } \\
\text { outsourced domestic and offshore services. }\end{array}$ & British Gas & $30 / 8 / 2012$ & Client \\
\hline $\begin{array}{l}\text { General Manager } \\
\text { Customer Service }\end{array}$ & $\begin{array}{l}\text { Predominantly managing outsourcing relationships and } \\
\text { custodian for customer service in the iiNet business }\end{array}$ & iiNet & $23 / 8 / 2012$ & Client \\
\hline $\begin{array}{l}\text { Senior Site Leader for } \\
\text { Amazon in South Africa. }\end{array}$ & $\begin{array}{l}\text { The country manager in South Africa for Amazon in charge } \\
\text { also of relationships with providers }\end{array}$ & Amázon & $26 / 8 / 2012$ & Client \\
\hline $\begin{array}{l}\text { Director of Content } \\
\text { Management and } \\
\text { International }\end{array}$ & $\begin{array}{l}\text { In charge of outsourced voice, contact centre relationships } \\
\text { with major clients - M\&S, Tesco, } \mathrm{O} 2 \text {, and for relations with } \\
\text { service providers internationally delivering that service }\end{array}$ & Capita & $5 / 7 / 2012$ & Client \\
\hline $\begin{array}{l}\text { Managing Director WNS } \\
\text { South Africa }\end{array}$ & $\begin{array}{l}\text { Responsible for the South Africa business. Full P\&L } \\
\text { responsibility, operational responsibility of the South } \\
\text { African operation. Includes decision-making and } \\
\text { implementation and management. }\end{array}$ & $\begin{array}{l}\text { WNS South } \\
\text { Africa }\end{array}$ & $23 / 8 / 2012$ & Provider \\
\hline General Manager & $\begin{array}{l}\text { Responsible for all operational and relationship matters on } \\
\text { the iiNet and Everything Everywhere accounts. }\end{array}$ & Merchants & $2 / 9 / 2012$ & Provider \\
\hline $\mathrm{CEO}$ & $\begin{array}{l}\text { In charge of relations with Capita, its customer base, and } \\
\text { SA operational service issues and business development }\end{array}$ & $\begin{array}{l}\text { Capita South } \\
\text { Africa/Full } \\
\text { Circle }\end{array}$ & $28 / 8 / 2012$ & Provider \\
\hline CEO & $\begin{array}{l}\text { In charge of financing, business development and client } \\
\text { relationships }\end{array}$ & Full Circle & $25 / 8 / 2012$ & Provider \\
\hline Managing Director & $\begin{array}{l}\text { In charge of a boutique consultancy specialising in } \\
\text { Business Process Outsourcing/Offshoring. }\end{array}$ & $\begin{array}{l}\text { Six Fingers } \\
\text { Consulting }\end{array}$ & $14 / 9 / 2012$ & Advisor \\
\hline $\begin{array}{l}\text { Practice Director, Global } \\
\text { Sourcing }\end{array}$ & $\begin{array}{l}\text { Responsible for analysing emerging trends in the global } \\
\text { sourcing industry and developing insights on offshore } \\
\text { locations. He is a regional expert on Africa and has helped } \\
\text { several countries grow their offshore services industry, } \\
\text { including South Africa. }\end{array}$ & Everest & $5 / 9 / 2012$ & Advisor \\
\hline CEO & $\begin{array}{l}\text { The CEO is in charge of this national association for } \\
\text { companies operating in the Business Process Service and } \\
\text { Outsourcing market. BPeSA creates an enabling } \\
\text { environment for members to network, share knowledge, } \\
\text { and collectively contribute to ensuring a vibrant South } \\
\text { African industry. }\end{array}$ & BPeSA & $14 / 9 / 2012$ & Advocate \\
\hline
\end{tabular}


To analyze the qualitative data, we first wrote up individual case studies, then extracted themes that emerged across the cases. We translated the "themes" into eight management lesson. All key informants reviewed the cases and management practices for accuracy, clarity, and publication permission. To demonstrate research validity and to bring the reader closer to the qualitative data, we include many direct quotes in the case descriptions and lessons (Klein \& Myers, 1999).

\section{Case synopses}

The four cases are similar in that the Western-based client companies all selected South Africa for customer care services, including voice, email, live chat, text, and other customer support services (see Table 2). The participants from the four client firms also echoed similar reasons for selecting South Africa, including economic value, high quality service and staff, high cultural compatibility, and favourable time zone. The four cases are dissimilar in the engagement model used - there are two outsourcing relationships, one captive centre that used a BOT model and one acquisition.

Table 2: Overview of the case studies

\begin{tabular}{c|c|c|c|l|l}
\hline $\begin{array}{c}\text { Case } \\
\text { Study }\end{array}$ & Client & Provider & Year & Services & \multicolumn{1}{|c}{$\begin{array}{c}\text { Engagement } \\
\text { Model }\end{array}$} \\
\hline 1 & British Gas & WNS South Africa & 2011 & Voice, email & Outsourcing \\
\hline 2 & iiNet & Merchants & 2008 & $\begin{array}{l}\text { Voice, email, social media, } \\
\text { compliance }\end{array}$ & Outsourcing \\
\hline 3 & Amazon & Full Circle & 2010 & Voice, email, live chat & $\begin{array}{l}\text { Captive Centre via a BOT } \\
\text { model }\end{array}$ \\
\hline 4 & $\begin{array}{c}\text { Capita } \\
\text { (acquirer) }\end{array}$ & $\begin{array}{l}\text { Full Circle } \\
\text { (acquired) }\end{array}$ & 2012 & Customer service and suppoi & Acquisition \\
\hline
\end{tabular}

Overall, the key informants all claim that their sourcing decisions are successful. We begin each case description with a quote that captures the participant's perception of the successful outcome. Next, we describe each client firm's decision to select South Africa as a BPO destination. We describe their reasons, provider/partnership selection, contractual governance, transition, and state of current operations.

\section{Case 1: British Gas}

\section{"WNS South Africa's customer satisfaction measures are hitting scores equal to our UK call centres." \\ General Manager, British Gas Residential}

As mentioned above, British Gas is a subsidiary of Centrica, a $£ 23$ billion British multinational utility company. British Gas is a seasoned outsourcing client, having outsourced certain processes for over 10 years. Initially, British Gas only outsourced back office processes, for example, a migration of billing systems to SAP. The company then began outsourcing customer-facing call centres domestically to provide resource flexibility. Customer call volumes are seasonal and outsourcing stabilized its resources without the need to hire and retrench employees to meet seasonal demand. Initially, British Gas's sourcing strategy was to keep customer-facing processes onshore, but cost pressures in the UK forced them to reconsider. The General Manager for British Gas's Residential customers (his title is General Manager, BG Residential) explained, "For many years we've said that we would not put our voice activity offshore; we would put back office and process activity offshore, but not voice. We ve been forced into the debate predominantly because of cost, but have been very selective to ensure the customer service offering will not be any different to what we offer onshore." The business case required significant cost savings, but the service levels had to equal those onshore.

Although India and the Philippines are the most popular destinations for offshore call centres, British Gas ruled out India and the Philippines because of the potential for negative customer reaction. British Gas considered South Africa because, in addition to cost savings, the accent is neutral, the business culture is similar to the UK, and the time zone is favourable. The General Manager for BG Residential and his team toured South African providers in Johannesburg, Durban, and Cape Town. After their visit, the General Manager concluded that South Africa was the preferred destination. He said: "We felt that we could actually find a partnership in South Africa that would have no detrimental impact to our customers." South Africa's grants also significantly affected British Gas's location selection. (South Africa's Department of Trade and Industry created grants aimed at attracting foreign investment in an effort to strengthen the country's presence in the business process outsourcing and offshoring industry. $)^{4}$

After vetting South Africa as the destination, British Gas issued a Request For Proposal. Many providers responded, and British Gas selected three for closer consideration. After provider pitches and rigorous due diligence, British Gas selected WNS South Africa because they had the best mix of commercial advantage, cultural values, and partnership

\footnotetext{
${ }^{4}$ See "Department of Trade and Industry announced a new set of incentives aimed at attracting foreign investment", at http:/www.southafrica.info/business/investing/incentives/bpoincentive080911.htm\#.UZEHI1 wo $7 Z 4$
} 
attitude. The General Manager remarked that "They appeared to be a business that we conld work with as a partner, not just as a supplier." WNS South Africa, formerly Fusion Outsourcing Services, was established in 2003 and employs over 1700 people, providing a range of outsourcing services including contact centre, customer care, and business continuity services to both South African and international clients.

In December 2011, Centrica, British Gas' parent company, signed a five-year, contract with WNS South Africa for incoming call centre services from Centrica's residential (UK) gas and electricity customers who have credit meters installed at their property. The initial scope of the contract involved the ramp up of 425 Full Time Equivalents (FTEs) over 18 months, with a target of potentially 625 FTEs. In March 2012, the contract was expanded to include 24 FTEs to support email correspondence with a potential to scale to 70 FTEs. In August of 2012, the contract was expanded a third time to include 120 FTEs to support incoming calls from British Gas's SME business customers. The contract is priced by hourly rates with metrics that track and reward performance.

According to key informant interviews, provider performance has been very good. In particular, the client rates the provider's performance against targets and business value gained as "very good". The client also rated service quality and the service experience as "very good". This was rated on tangible physical evidence of delivery, reliability (accuracy and dependability), assurance (giving confidence and trust), and empathy (attention to user). The General Manager of BG Residential concluded: "I think the relationship is excellent. We're really happy with our experience of how this venture has gone. I think the team has been first class. We're delighted we chose them. They've been a real strong partner and a strong integral part of our business strategy moving forward."

\section{Case 2: iiNet}

"Overall, our relationship with Merchants is a ten out of ten. We are that closely aligned. The blood, sweat, and tears that both parties went through to make this successful-the relationship has always been extremely strong."

General Manager of Customer Service, iiNet

iiNet is Australia's second largest internet service provider. From its inception in 1993, iiNet sought to exceed customer satisfaction levels, which are notoriously low in the telecommunications sector according to iiNet's CEO. To build a culture of high customer service, iiNet's incentives for all employees in all departments are based on customer feedback. For customer service representatives, for example, $100 \%$ of their bonuses are based on whether the customer is satisfied at the end of a call.

By 2007, iiNet's three call centres in Perth, Sydney, and Auckland were operating at full capacity. iiNet's CEO began to look for another location to set up a fourth call centre. Initially, the search focused on the Philippines and India. An iiNet employee who was working in Australia suggested that iiNet should consider his homeland, South Africa. iiNet's CEO said, "While it was initially met with a bit more amusement than credibility, we decided, Hold on a minute, let's flush this out because the time zone is very attractive." "Cape Town was added to the CEO's itinerary as he and some other iiNet executives scouted locations in Manila and Bangalore.

Cape Town's time zone is six hours west of Perth, so Auckland to Cape Town covers 10 time zones, meaning iiNet could provide 24 hour call support without having to make any employee work earlier than $6 \mathrm{am}$ or later than $8 \mathrm{pm}$. iiNet's General Manager for Customer Service explained the importance of Cape Town's time zone coverage: "It was really a search to find a location that delivered the ability to have that follow-the-sun methodology while making sure that our staff had a worklife balance." Favourable costs (although, according to iiNet respondents, South Africa is not as cheap for them as India or the Philippines), similarities to Australia in terms of language and culture, and an apparently eager workforce were other reasons iiNet selected South Africa for its newest call centre.

Merchants had the experience iiNet was looking for because it had a 30-year track record of delivering customer contact centre solutions. Furthermore, Merchants understands telecommunications companies because telecom clients generate $50 \%$ to $55 \%$ of Merchants' revenues. ${ }^{6}$ Mostly, iiNet was attracted to Merchants ${ }^{3}$ collaborative approach to outsourcing that focused on customised solutions. Merchants also had experience and expertise in developing both their own centres in Cape Town, Durban, and Johannesburg ${ }^{7}$ as well developing new contact centres for clients. iiNet's General Manager for Customer Service explained how Merchants ${ }^{*}$ approach differs from traditional outsourcing: "It's certainly not a traditional outsource relationship we have with Merchants. For all intents and purposes, the site here, the building, the facilities, everything we do from how we recruit to how we train is very much iiNet. Merchants is flexible and were quite happy to work with us to provide everything we needed."

In 2008, iiNet and Merchants signed their first contract for 144 seats. The initial contract duration was 17 months. Merchants built a call centre facility that replicated iiNet's other call centres in every way, from facilities and technologies to human resource policies. In fitting out the new facility, the partners had to install iiNet's network at the Cape Town facility because iiNet wanted seamless transitions between the Cape Town facility and its call

\footnotetext{
${ }^{5}$ You-tube video, Interview with Mike Malone, http://www.youtube.com/ watch? $\mathrm{v}=6 \mathrm{~K} 8 \mathrm{n} 4 \mathrm{LR}$ IHPQ

http://www.offshoringsouthafrica.com/wp-content/uploads/downloads/ 2011/05/I_Merchants-Supplier-Profile_Final.pdf

http://www.offshoringsouthafrica.com/ wp-content/uploads/downloads/ 2011/05/1_Merchants-Supplier-Profile_Final.pdf
} 
centres in Australia and New Zealand. Merchants also replicated the physical facilities (such as breakout rooms used by other iiNet centres), including pool tables, soccer games, and videogame PlayStations. As iiNet's General Manager described it: "If you walked into this centre and then walk into our centre in Sydney, Melbourne, Auckland, or Perth, it would look and feel exactly the same."

The transition and start-up phase of this relationship were very successful, in large part to the investment in resources, leadership, and staff that both partners dedicated to the project. iiNet's General Manager for Customer Service concluded the discussion of the transition by stating: "We really micro-managed on both sides, both Merchants and ourselves." The initial contract between iiNet and Merchants was extended twice. By fourth quarter 2012 , iiNet had over 2000 people working in call centres in Perth, Sydney, Melbourne, Adelaide, Canberra, Auckland, and Cape Town. The staff in Cape Town has grown from 144 people to over 400 and services have expanded to include not only voice, but email, social media, and regulatory compliance. The staff in the Cape Town facility performs as well as all the other call centres. According to iiNet's General Manager for Customer Service: "Our number one measure is customer experience and the fact that Cape Town performs on par with every other contact centre in my network, shows that they understand and deliver on those requirements."

\section{Case 3: Amazon}

"Full Circle has been a great partner during the first phase of setting up Amazon's customer service centre in South Africa. They delivered a turnkey solution by hosting us in their Model Office, while remaining flexible, professional, and hands-on in their approach to working with us. We have felt fully supported by all members of the Full Circle team..."

Senior Site Leader, Amazon ${ }^{8}$

As the world's largest online retailer, Amazon earned US $\$ 48$ billion in revenue in 2011 and employed 69,000 people. Amazon's evolving business model relies heavily on its innovative IT systems. While much of its software is developed at its headquarters in Seattle, Washington, Amazon also has software development centres across the globe. Amazon first entered South Africa in 2005 by setting up a software development centre in Cape Town, focusing on Amazon's Elastic Cloud Computing business. The success of the development centre gave Amazon the confidence to consider moving front-end customer services to South Africa.

Amazon's Senior Site Leader said that South Africa was an attractive location for call centres for a few reasons. First, as

\footnotetext{
${ }^{8}$ The business entity in South Africa is Amazon Development Centre South Africa. Note that US-based Amazon.com which is a US company, does not have a presence in South Africa; also http://www fullcirclesa.com/about_clients.php
}

a retailer, Amazon's busiest season is Christmas so having customer support in the Southern Hemisphere ensures that employees can get to work easily because it's summertime there. Amazon's other customer contact centres are predominantly located in the Northern Hemisphere and sometimes employees cannot commute in severe winter weather. Next, time zone affinity was a location factor. The Senior Site Leader said: "South Africa is aligned with European time zones. That makes it easy for us to provide service during their same hours of the day. Then it also enables us to have a site to provide overnight support for our North American businesses." Finally, Amazon deemed that South Africa has a language diversity that is difficult to find in other location. Although English and German comprise the bulk of the languages Amazon employees need, Amazon also needs some French, Spanish, Italian, and Japanese language capabilities. The Senior Site Leader said, "There are very few places in the world that you can go and have that much language diversity in one particular site."

Thus, Amazon had compelling reasons for establishing call centre capabilities in South Africa, but it did not have the resources or time to build a 1000 plus seat captive centre from scratch in its first year of call centre operation. Amazon engaged the South African-based BPO service provider, Full Circle, in 2010 to assist in, effectively, a "build operate transfer" (BOT) model (Vashistha \& Vashistha, 2006). Full Circle helps international businesses, like Amazon, build service delivery capabilities in South Africa with its version of a BOT model it calls the "Model Office" solution. The Model Office is a facility that allows clients to experience customer service delivery from South Africa for a trial period prior to making any long-term investment or commitment with regard to location or specific operating model. For those clients wanting to move beyond the Model Office, Full Circle help clients transition work to a client's own captive centre or even to other service providers." The CEO of Full Circle explained: "We affered them the Model Office as an option which meant that they could literally be up and running within two months, with the connectivity and the staff trained, out of Cape Town... So we literally helped them with the entire transition into our Model Office where they grew to approximately 220 seats. ${ }^{3 s}$

While Amazon was providing customer services from the Model Office, Full Circle introduced Amazon to all the South African suppliers that would become its long-term associates, including recruitment partners, connectivity partners, and IT partners. Of course, the establishment of a captive centre is never easy and Amazon had to overcome a number of challenges in South Africa. Amazon had trouble finding enough staff with both verbal and written fluency in German. When staff shortages were severe, Amazon partnered with foreign embassies and consulates in Cape Town in order to access the supply of workers with the requisite capabilities. As an early entrant into South Africa, Amazon had difficulties obtaining immigration documents

\footnotetext{
${ }^{9}$ See http://www.fullcirclesa.com/docs/brochure.pdf
} 
and hired an immigration specialist to manage that process. (The South African Home Affairs department has since improved the immigration process according to key informants.) Although research participants have cited South Africa's infrastructure as a country adyantage, Amazon experienced difficulties with establishing a broadband network because most internet service providers in South Africa had never installed the size of pipe required by Amazon (able to handle speeds of 100 megabits per second). ${ }^{10}$ Amazon overcame these obstacles, and today, Amazon's captive centre for customer services has about 1 100 employees. The centre provides a range of phone, email, and live chat services, including inbound customer service for the US, UK, and German retail businesses, "how to" assistance and more technical support for Amazon's Kindle e-reader, and support for the Amazon's US digital businesses, including Amazon Instant Video, the MP3 store, Cloud Drive and Cloud Player. ${ }^{11}$

\section{Case 4: Capita}

\begin{abstract}
"We've got the humility to recognize that it's different in South Africa than in the UK. So we've bought a company called Full Circle with a management team where you have the experience both in the UK and South Africa of running outsourced contact centre operations. " Director of Customer Management and International, Capita
\end{abstract}

Capita is the UK's leading BPO and professional services company in terms of anmual turnover, delivering back office administration and front office customer contact services to private and public sector organisations based in the UK and Ireland. In July 2012, Capita acquired Full Circle because it wanted to establish a presence in South Africa to complement its global service delivery portfolio. We detail why Capita chose South Africa and Full Circle.

Capita already had delivery centres in the UK, Ireland, Poland, the Channel Islands, Dubai, and India. Why did Capita look to acquire a firm in South Africa? According to Capita's Director of Customer Management and International, Capita selected South Africa for four reasons: client demand, sound infrastructure, compatible culture, and economic value. Firstly, Capita's clients were demanding offshore location alternatives. He said: "We start with the clients because they re probably the most important part in this decision to select South Africa. Offshoring is well established as being on their agenda but clients want choice and flexibility." Capita found that South Africa offered a value proposition that was different from other offshore locations. He continued by stating: "Now, why South Africa? South Africa is really a response to clients for whom lowcost voice services out of India are not acceptable. For these clients, South Africa is perceived as being more 'acceptable' in delivering low-cost voice capability." Capita assessed that

\footnotetext{
${ }^{10}$ Ovum Group (2012), "Amazon Case Study"

"Ovum Group (2012), "Amazon Case Study"
}

South Africa also had the time zone advantage compared to other alternative offshore destinations like the Philippines.

Secondly, Capita selected South Africa because of good infrastructure. The Director of Customer Management and International noted that South Africa's exemplary hosting of the World Cup increased people's confidence in the infrastructure. The CEO of Full Circle added: "The infrastructure has improved over the past five years; you have the connectivity and redundancy because of all the new lines into South Africa."

Thirdly, Capita selected South Africa because UK business executives were comfortable with South Africa's culture. Capita's Director of Customer Management and International mentioned that many clients have either interacted with the large ex-pat South African community in the UK or have been to South Africa and, in particular, the Western Cape. He said: "They've experienced a hotel, a restaurant, a nightclub, going to a sports event, and they see the service ethos. "The South African culture is a bit more open than British culture, but that too has been an attractive feature. Finally, the economics in South Africa are attractive because of the government's investment grants, which according to Capita's Director "makes it not equivalent to India, but close and therefore positions South Africa as able to compete with the India voice proposition."

Thus, Capita selected South Africa as its next destination. Next, Capita had to decide to build a captive centre or acquire a company. Capita decided to acquire Full Circle because it had experience both in the UK where most of Capita's clients are located and in South Africa. Capita"s Director explained the acquisition strategy: "We can operate as an outsourcer in South Africa ourselves, but we shouldn't kid ourselves that setting it up is straightforward. So effectively what we've done, we've acquired an accelerated start-up capability."

\section{Lessons for Western-based client firms}

The research sought to extract lessons for other Westernbased clients considering South Africa as an offshore destination by answering two questions about Westernbased clients already sourcing BPO services from South Africa:

1. Why do Western-based client firms select South Africa as a destination for BPO services?

2. Which management practices lead to successful sourcing outcomes in South Africa?

For Western-based client firms considering South Africa as a destination for outsourcing, for erecting a captive centre, or for acquiring an existing BPO provider, eight lessons arise from the case studies (see Table 3). Two lessons pertain to country selection criteria associated with the first research question: First, South Africa complements the global portfolio for many Western-based companies, particularly for those companies that already have centres 
established in India, the Philippines, and Eastern Europe. Second, South Africa's value proposition cannot only be about costs because other locations are cheaper; South Africa's value proposition is about overall economic value, high quality staff, high cultural compatibility, and a favourable time zone.

Lessons 3 through 8 pertain to the second research question about management practices that lead to successful outcomes. Four of these lessons corroborate prior BPO research about capabilities and relational governance. The final lesson was not directly asked of participants but emerged as a lesson: BPO relationships in South Africa demonstrate strong Corporate Social Responsibility (CSR) by transforming the lives of employees and the broader communities. Each lesson is explained in more detail.

\section{Table 3: Lessons illustrated by case study clients}

\begin{tabular}{|c|c|c|c|c|}
\hline \multirow{2}{*}{ Lesson } & \multicolumn{4}{|c|}{ Clients } \\
\hline & British Gas & iiNet & Amazon & Capita \\
\hline $\begin{array}{l}\text { 1. South Africa complements the global delivery portfolio for many } \\
\text { international companies }\end{array}$ & & $\mathrm{X}$ & & $\mathrm{X}$ \\
\hline 2. South Africa's value proposition cannot only be about costs & $\mathrm{X}$ & $\mathrm{X}$ & $\mathrm{X}$ & $\mathrm{X}$ \\
\hline 3. For best results, find a partner not a vendor & $\mathrm{X}$ & $\mathrm{X}$ & $\mathrm{X}$ & $\mathrm{X}$ \\
\hline 4. Invest in enough resources, particularly leadership, during the transition & $\mathrm{X}$ & $\mathrm{X}$ & $\mathrm{X}$ & \\
\hline 5. Resolve issues, don't assign blame & $\mathrm{X}$ & & & \\
\hline 6. Protect the providers' commercial interests & $\mathrm{X}$ & & & \\
\hline 7. Governance: when to lead, when to follow & $\mathrm{X}$ & $\mathrm{X}$ & $\mathrm{X}$ & $\mathrm{X}$ \\
\hline 8. BPO relationships transform lives and communities & $\mathrm{X}$ & $\mathrm{X}$ & & \\
\hline
\end{tabular}

Lesson 1: South Africa complements the global delivery portfolio for many client firms. The literature posits that managers base location decisions by assessing a country's business, financial, and human resource attractiveness (Malos, 2009; Doh, Bunyaratavej, \& Hahn, 2009). Our research finds that country location decisions are not made in isolation, but rather managers consider new locations visá-vis prior location decisions. For companies like iiNet and Capita, South Africa was a welcome addition to their existing service centre locations. For iiNet, South Africa complemented its other call centre locations in Perth, Sydney, and Auckland. Cape Town's time zone would mean that iiNet could provide 24 hour customer support without having to make employees work the "grave yard" shift. Most of Capita's delivery centres are based in the UK because of the advantages of close proximity to clients, deep domain understanding, high cultural compatibility, reduced business risks, and rapid responsiveness, but the UK centres have the highest relative costs. Some clients want lower costs and thus need offshore destination options. Capita's nearshoring centres in Northern Ireland are attractive to UK clients, particularly for clients that have never offshored services before. Capita's Polish delivery centre in Krakow is further away from Northern Ireland, but has its advantages including lower wages, is still within the European Union, can scale multi-lingual capabilities, and has high mobility of the workforce (e.g., fewer visa issues). India, obviously, has the best cost advantage relative to other locations. Capita added Cape Town to its global delivery platform because it offered a unique mix of cost advantage, front office capabilities, accent neutrality, high cultural compatibility, and favourable time zone. Capita's Director explained the types of UK clients selecting the South African delivery centre, "The clients that we re bringing down [to South Africa] are typically front-office customer services, collections, a bit of outbound telesales in the telecoms and technology space. We've also got interest from within Capita across a range of businesses to do with front office; across different sectors, financial services, technology, telecoms, and utilities."

Lesson 2: South Africa's value proposition cannot only be about costs. Transaction Cost Economics posits that managers will select the low cost sourcing alternative, but clients and providers from all the case studies reported that South Africa is not the cheapest location. If cost is the major criterion, India and the Philippines still prevail as low cost leaders. Instead, South Africa's value proposition is about overall economic value, high quality staff, high cultural compatibility, and a favourable time zone. To illustrate this lesson, we draw upon iiNet's story. In selecting any destination for a new call centre, iiNet's main concern is customer service excellence. iiNet selected South Africa and Merchants because of the overall value, not because they were the cheapest option. According to iiNet's General Manager: "South Africa is certainly not the cheapest outsourced destination" and "Merchants may not be the cheapest outsourcer, by any stretch of the imagination, but we were happy with the business case as long as we didn't substitute what we had to do [for customer service]." In fact, iiNet walked away from a lower cost destination because senior management did not think they could get the same level of quality as they do in Australia, New Zealand, and Cape Town.

Lesson 3: For best results, find a partner not a vendor. Consistent with the BPO research on relational governance, the clients in this study hold an attitude called the "Partnership View" in which a client regards the provider as a strategic partner rather than as an opportunistic vendor (Lacity et al, . 2011; Lacity \& Willcocks, 2013; Sen \& Shiel, 2006). What clients like British Gas, Amazon, and iiNet 
mean by "partnership" is that the partners are flexible, open, honest, and transparent with each other. For example, the General Manager for BG Residential said: "I think we're very honest. We're a very inclusive organisation in the way we run things as well. I think we try to make sure they're involved in all of the things that we are planning to do." The Managing Director for WNS South Africa concurred: "I really think it's a true partnership. It's not a question of you're the supplier, you sort it out, we're dumping everything an you, make it happen. It's a shared approach." Research participants from iiNet and Merchants spoke several times about how their relationships are flexible. The General Manager for Customer Service said of Merchants: "[With Merchants], it is so far from a traditional outsource arrangement... it's about how do we get that partnership going...If I look at Merchants, I certainly think flexibility is very high up there from a behavioral trait they have. They were willing to work with us. They were willing to do what we needed done."

Lesson 4: Invest in enough resources, particularly leadership, during transition. In previous offshore outsourcing relationship research (Carmel \& Tjia, 2005; Dibbern, Winkler \& Heinzl, 2008; Lacity \& Rottman, 2008), many clients failed to invest in enough resources during the transition because they did not want to erode the financial business case. Yet, service excellence cannot happen without investing in resources like onsite managers and investments in knowledge transfer (e.g., shadowing, mentoring, and training) (Carmel \& Tjia, 2005). Across all the South African cases, clients mentioned the value of investing in enough resources, particularly leadership, during transition. For example, British Gas assigned a fulltime operations manager to work daily at Fusion's delivery centre. This onsite liaison is obviously a costly investment for British Gas, but it is a best practice to protect quality. The iiNet case also illustrates the lesson of investing in enough leaders when launching a new business. iiNet sent a large team of $\mathrm{IT}_{\text {, training, human resources, and }}$ management staff from Australia to South Africa to help with the transition. iiNet's General Manager for Customer Service said: "It certainly wasn't a case of we put down our business requirements on a piece of paper, gave it to them and expected them to do it. The fact that we were so involved and were so vested in the outcome of this venture from day one, meant it became a success."

At Amazon, the participants wished that they had assigned more leaders on the ground in South Africa during the launch. According to participants, many companies prescribe rigid management-to-employee ratios, like having one manager for every 20 employees. But during a start-up, these ratios might need to be doubled or even tripled. When Western-based clients are in a new country, they need to adapt company policies to a new country's labour laws and must understand the new environment and how it will function. The learning curve is always steeper than anticipated. Amazon's Senior Site Leader advised: " $I$ 'd say. not to under-invest in your leadership and in your support groups at the beginning which is what people will tend to do to cut cost and think, 'Oh we're just a few employees. We don't need that many people in HR from start up. We can add those later on."

Lesson 5: Resolve issues, don't assign blame. All services-whether insourced or outsourced-will have issues that disrupt performance. In good outsourcing relationships, partners are transparent about service issues and seek to resolve them together (Lacity \& Willcocks, 2013). British Gas and WNS South Africa illustrate this lesson well. On this account, sample service issues included a problematic IS infrastructure, higher than expected attrition rate, and middle managers who were too "hands off". British Gas, for example, is accustomed to middle managers who listen to calls daily and who coach frontline employees. Conversely, in South Africa, middle managers are accustomed to delegating work to the teams. The partners are very honest and open with each other to resolve all service issues. The General Manager for BG Residential explained: "We are very direct with our feedback." The Managing Director for WNS South Africa concurred stating that: "The client's willingness and almost insistence on feedback on how they can improve their customers experience on their side immediately creates a culture of improvement and a focus on how we do can things differently."

Lesson 6: Protect the provider's commercial interests. From previous ITO and BPO research on high-performing relationships (Kern et al., 2002; Lacity \& Willcocks, 2012), we learned that each partner cares about the other party's commercial interests. This is not altruism; it is actually in the client's best interest to care about and protect the provider's commercial interests and vice versa because service performance is directly tied to financial performance. In prior ITO research, for example, Kern et al. (2002) examined what happened to outsourcing performance when providers failed to meet their margins. In 15 cases of missed provider margins, 12 clients $(80 \%)$ reported poor outsourcing performance. In 70 cases when the provider met its target margins, only 19 clients (27\%) reported poor outsourcing performance (Kern et al., 2002). Mature outsourcing clients understand this lesson well. For example, the General Manager for BG Residential said it's very important for clients to make sure that providers can make a fair return. During the economic recession, procurement specialists can squeeze quite a bit from providers, but service will suffer if providers don't have "wiggle room". The General Manager said: "There's some interesting ways that you can cut your contracts and your commercials but I do think you have to do it with partnership in mind. If you're just doing it to save money, then the reality is it's a short-term solution, not a long-term investment."

Lesson 7: Governance: when to lead, when to follow. Prior BPO research found that contractual and relational governance are vital to BPO success (Handley \& Benton, 2009; Lacity et al. 2011; Niranjan et al., 2007; Wüllenweber et al. 2008). One particular aspect of governance was raised in our case studies that was not previously discussed in prior BPO research. After Western- 
based clients committed to South Africa by either building or buying a service centre, should the home office impose all, some, or none of its own rules, processes, and values on the local service centre? The four client firms in this research represent the span of governance options, with iiNet imposing all corporate policies and with Amazon imposing very few. Capita mostly delegates, but does insist on certain global standards for customer routines. British Gas rigorously defines measures and then verifies performance with inspections.

For iiNet, the answer is largely to replicate all of their policies on Merchants in South Africa because they want a consistent customer service experience. iiNet's General Manager for Customer Service explained, "I've worked in a number of different companies and iiNet stands out because they do not substitute their culture no matter what the benefit is. At the end of the day, it has to suit our culture or it's just not on the table."

For Amazon, the answer is largely to trust the South Africans to do their job. According to a case study by Peter Ryan, Practice Leader for Ovum's service team, Amazon aims to empower its employees by trusting their judgment and giving them all the tools necessary to resolve the customer's issues themselves. Amazon believes that employee empowerment is one of the major reasons why the Cape Town facility has little absenteeism, with low attrition. ${ }^{12}$

Since Capita acquired Full Circle, the overall spirit has been to trust the senior leaders from Full Circle, "I can't pontificate about what to do in South Africa. It's not my role," said one Capita Director. Recall his words, "We've got the humility to recognize that it's different in South Africa than in the UK. "For example, Capita recognized that human resources management in South Africa would be different-best to leave human resources to Full Circle. Capita made the same decision when faced with the question of whose IT solution should be used-Capita's for consistency or Full Circle's for continuity? According to Capita's Director of Customer Management and International, Full Circle's IT solution was used. He said: "About the IT solution they're going to use to connect to the Capita-now we could do the classic things some firms do and impose a solution from Group. But we re absolutely not going to do that. I think it's hugely important for them to feel like they are genuinely accountable for the outcomes that they control. I think that's important for reinforcing the confidence and helping to make them successful. "However, Capita does take the lead on some issues. For example, Capita sent a number of operational managers from the UKK to South Africa to help the team establish client routines and to further develop middle management capabilities in the South African delivery centre.

At British Gas, the General Manager of BG Residential advises that clients should have absolute clarity about what

${ }^{12}$ Ovum Group (2012), "Amazon Case Study" they expect from the service, develop clear metrics to track those expectations, and then be actively involved in inspecting those services. The last part of that statementthe inspections - is somewhat unique from the lessons emerging from our other cases. Most clients believe that if expectations are clear and metrics are clear, then frequent, hands-on inspections are not needed. British Gas is highly focused on customer service so that in all their call centres, even the most senior executives listen to call centre calls. The General Manager recognizes that he and his team are intrusive: "They are professionals in their own environment, and they understand the market. I presume they would want us to give them a little bit more rope to do things their way rather than always our way. "This is part of British Gas's customer-service culture and undoubtedly accounts for the customer service awards they have received. ${ }^{13}$

Lesson 8: Corporate Social Responsibility: BPO relationships transform lives and communities. One lesson that emerged from the BPO interviews that was not directly solicited on the interview schedule was the focus on Corporate Social Responsibility (CSR) by participants. CSR is a major priority for USA, Canadian, European and Australian-based firms (Babin \& Nicholson, 2012; Porter \& Kramer, 2006; Porter Kramer, M. 2011; Viviers \& Eccles, 2012) and is clearly a priority for two of the case study firms. The clients and providers from these two cases described their CSR practices by explaining how their BPO relationships transform the lives of their employees and the communities in which they operate. British Gas encourages employees to help their communities. ${ }^{14}$ In South Africa, British Gas and WNS South Africa care not only about their employees but also about the communities in which they operate. Helping Hands is one of their preferred charities, based in the Carterville township of Wellington. It supports children that have been affected by HIV/AIDS or fetal alcohol syndrome. WNS South Africa found in this charity a support structure to equip the affected children with the necessary life skills to eventually take responsibility for their own well-being. ${ }^{15}$ inet serves as another example of CSR. iiNet's General Manager for Customer Service said, "For us in Cape Town, you know, we do a number of things like supporting local charities, local initiatives, and things like that. That also highlights how much we care." iiNet's General Manager for Customer Service also discussed the BPO industry's effect on South African employees. He said, "When we started this business in Cape Town, it was very clear to us that we were actually changing people's lives. So, for instance, a lot of our staff before they came into training and before they came into itNet, had never used the internet before, yet they're servicing customers at an ISP."

\footnotetext{
${ }^{13}$ British Gas's Call Centre in Cardiff has been named both 'European Call Centre of the Year' and 'Best Centre to Work for in Europe' for the second year numing. The company also won the award for 'Large Contact Centre of the Year (over 100 seats)' in 2010, and was also highly commended for 'Best Centre for Customer Service'.

${ }^{14} \mathrm{http}: / /$ www.britishgas.co.uk/about-us/about-British-Gas/awards.html ${ }^{15}$ Presentation "British Gas Credit Energy in partnership with WNS Fusion in South Africa"
} 


\section{Limitations of the study and future research}

This research has a number of limitations. Key informant interviews have two main drawbacks, namely informant bias and random error (Kumar et al,. 1993). Prior research suggested that multiple informants per site can increase the reliability and validity of findings (Seidler,1974). For all of the cases, we interviewed at least two key informants, and the client and provider perspectives were represented for all cases. The four selected cases were a limited sample in that all focused on front-office services, i.e., customer support and call centre services. All cases are based in Cape Town. South Africa's BPO sector includes other, though as yet not primary, BPO capabilities, including legal and financial services that are not represented in the present study. Other South African cities, most notably Durban and Johannesburg, are also important BPO hubs and worthy of further examination, though, at present, Cape Town represents the majority of captive and $\mathrm{BPO}$ expenditure in South Africa according to BPeSA. These cities and services are the subject of a future study by the authors.

\section{Conclusion}

Based on four case studies, the research finds that, for the UK, US, and Australian client companies in this study, South Africa's value proposition is not just based on costs as other locations are often cheaper. South Africa's value proposition is about overall economic value, high quality service and staff, strong cultural compatibility, and a favourable time zone. The findings reveal also that South Africa complements the global portfolio for these client firms that already have BPO centres in India, the Philippines, and Eastern Europe. Pertaining to best practices, this research found that many general lessons from prior BPO research is relevant for the context of South Africa. Western-based clients choosing to receive business services from South Africa using outsourcing, captive centre, or acquisition engagement models need to adopt sound governance practices, particularly in terms of treating the provider as a partner, resolving issues in a collaborative manner, protecting's the provider's commercial interests, and designing effective governance structures that balance home office needs with South Africa's needs. Westernbased clients also need to invest in enough resources, particularly leadership, to help develop the provider's middle management capabilities.

\section{Acknowledgements}

We thank BPeSA (Business Process Enabling South Africa) for sponsoring this research. In particular, we are grateful to Mr. Gareth Pritchard for his support, and register sincere gratitude to all the research participants for giving so unreservedly of their information and time.

\section{References}

Babin, R. \& Nicholson, B. 2012. Sustainable global outsourcing. London: Palgrave.

Barney, J. 1991. 'Firm resources and sustained competitive advantage', Joumal of Management, 17(1): 99-120.

Barney, J. 1999. 'How a firm's capabilities affect boundary decisions', Slaan Management Review, 40(3):137-145.

Bloor, M. \& Wood, F. 2013. Key informant. Keywords in qualitative methods. Thousand Oaks: Sage Publications.

Borman, M. 2006. 'Applying multiple perspectives to the BPO decision: A case study of call centers in Australia', Journal of Information Technology, 21:99-115.

Business Wire 7 February 2011. Everest Group Q4 report: Outsourcing transactions reach 36-month high, mega deals boost market growth.

Carmel, E. \& Tjia, P. 2005. Offshoring information technology: Sourcing and outsourcing to a global workforce. Cambridge: Cambridge University Press.

Coase, R. H. 1937. 'The nature of the firm', Economica, 4: 386-405.

Creswell, J. 1998. Qualitative inquiry and research design: Choosing among five traditions. Thousand Oaks; Sage Publications.

Denzin, N. \& Lincoln, Y. 2000. Handbook of qualitative research. 2nd Edition. Thousand Oaks: Sage Publications.

Dibbern, J., Winkler, J. \& Heinzl, A. 2008. 'Explaining variations in client extra costs between software projects offshored to India', MIS Quarterly, 32(2): 333-366.

DiMaggio, P., \& Powell, W. 1991. The iron cage revisited: Institutional isomorphism and collective rationality in organizational fields. In Powell, W. \& DiMaggio, P. (eds.). The new institutionalism in organizational analysis, Chicago: The University of Chicago Press, pp. 63-82.

Dobrzykowski, D., Tran, O. \& Tarafdar, M. 2010. 'Value co-creation and resource based perspectives for strategic sourcing,' Strategic Outsourcing: An International Journal, 3(2): 106-127.

Doh, J., Bunyaratavej, K., \& Hahn, E. 2009. 'Separable but not equal: The location determinants of discrete services offshoring activities,' Journal of International Business Studies, 40: 926-943.

Domberger, S. 1998. The contracting organization: A strategic guide to outsourcing. Oxford: Oxford University Press. 
Eisenhardt, K. 1985. 'Control: Organizational and economic approaches', Management Science, 31(2): 134-150.

Eisenhardt, K. 1989. "Agency theory: An assessment and review, The Academy of Management Review, 14(1): 57 76.

Ekeh, P. 1974. Social exchange theory: The two traditions. Boston: Harvard University Press.

Elmendorf, W. \& Luloff, A. 2006. 'Using key informant interviews to better understand open space conversation in a developing watershed', Arboriculture \& Urban Forestry, 32(2): 54-61.

Fontana, A. \& Frey, J. 1994. Interviewing: The art of science. In Denzin, N. \& Lincoln, Y. (Eds.). Handbook of qualitative research. Thousand Oaks: Sage Publications, pp. 361-376.

Handley, S. \& Benton, W.C. 2009. 'Unlocking the business outsourcing process model', Journal of Operations Management, 27(5): 344-361.

Harris, J., Hale, K., Brown, R., Young, A. \& Morikawa, C. 2010. Outsourcing worldwide: Forecast Database. Gartner Report, 13 September, 2010, [online] URL: http:/ Www.gartner.com/ id $=486175$.

Hindle, J., Willcocks, L., Feeny, D. \& Lacity, M. 2003. 'Value-added outsourcing at Lloyd's and BAE Systems', Knowledge Management Review, 6(4): 28-31.

Kern, T. Willcocks, L. \& Van Heck, E. 2002. 'The winners curse in it outsourcing: Strategies for avoiding relational trauma" , California Management Review, 44(2): 47-69.

Kim, G. 2008. 'E-business strategy in Western Europe: Offshore BPO model perspective', Business Process Management, 14(6): 813-828.

Kim, G. \& Kim, S. 2008. 'Exploratory study on effective control structure in global business process sourcing', Information Resources Management Journal, 21(3): 101118.

Klein, H. \& Myers, M. 1999. 'A set of principles for conducting and evaluating interpretive field studies', MIS Quarterly, 23(1): 67-88.

Kumar, N., Stern, L., and Anderson, J. 'Conducting Interorganizational Research Using Key Informants', Academy of Management Joumal, 36(6): 1623-1651.

Kvale, S. 1996. Interviews: An introduction to qualitative research interviewing. Thousand Oaks: Sage Publications.

Lacity, M. \& Rottman, J. 2008. Offshore outsourcing of IT work. United Kingdom: Palgrave.
Lacity, M. \& Willcocks, L. 2009. Information systems and outsourcing: Studies in theory and practice. London: Palgrave.

Lacity, M. \& Willcocks, P. 2012. Advanced outsourcing practice: Rethinking ITO, BPO, and cloud services. London: Palgrave.

Lacity, M. \& Willcocks, L. 2013. Mastering highperformance: Resolving conflicts in business process outsourcing relationships', Accenture, [online] URL: http://www.accenture.com/Microsites/highperfbpo/ Documents/Scripts/want-to-learn-more/HighPerformance BPO-Resolving-Conflicts-BPO-Relationships.pdf.

Lacity, M., Solomon, S., Yan, A. \& Willcocks, L. 2011. 'Business process outsourcing studies: A critical review and research directions', Journal of Information Technology, 26(4): 221-258.

Lam, W. \& Chua, A. 2009. "An analysis of knowledge outsourcing at Eduware', Aslib Proceedings New Information Perspectives, 61(5):424 435.

MacNeil, I. 1980. The new social contract: An inquiry into madern contractual relations. New London: Yale University Press.

Mahmoodzadeh, E., Jalalinia, S. \& Yazdi, F, 2009. "A business process outsourcing framework based on business process management and knowledge management', Business Process Management Journal, 15(6): 845-864.

Mahoney, C. 1997. Common qualitative techniques. In User-friendly handbook for mixed method evaluations. Published by the Division of Research, Evaluation and Communication for the National Science Foundation, publication number NSF97-153: 1-17.

Malos, M. 2009. 'Regulatory effects and strategic global staffing profiles: Beyond cost concerns in evaluating offshore location attractiveness ${ }^{*}$, Employee Responsibilities and Rights Journal, 22: 113-131.

Mehta, A., Armenakis, A., Mehta, N. \& Irani, F. 2006. 'Challenges and opportunities of business process outsourcing", Journal of Labor Research, 27(3): 323-337.

Miles, R. \& Snow, C. 1978. Organizational strategy, structure and process. New York: McGraw-Hill Revised edition 2003 by Stanford University Press, Stanford.

Nahapiet, J. \& Ghosal, S. 1998. 'Social capital, intellectual capital, and the organizational advantage', Academy of Management Review, 23(2): 242-265.

Niranjan, T., Saxena, K. \& Bharadwaj, S. 2007. 'Processoriented taxonomy of BPOs: An exploratory study", Business Process Management Journal, 13(4); 588-606. 
Oshri, I. 2011. Offshoring strategies: Evolving captive center models. Cambridge Massachusetts; MIT Press.

Oshri, L. \& Van Uhm, B. 2012. 'A historical review of the information technology and business process captive centre sector', Journal of Information Technology, 27(4): 270-284.

Parsons, J. 2013. Key informant. In Lavrakas, P. (Ed.). Encyclopedia of survey research method. Thousand Oaks: Sage Publications.

Pfeffer, J. 1981. Power in organizations. Marshfield, Massachusetts: Pitman Pub.

Pfeffer, J. 1994. Managing with power: Politics and influence in organizations. Harvard Business School Press, Boston.

Pfeffer, J. \& Salancik, G. 1978. The external control of organizations: A resource dependence perspective. New York: Harper \& Row.

Ponterotto, J. \& Casas, M. 1991. Handbook of racial/ethnic minority counseling research. Springfield: Charles C Thomas Press.

Porter, M. 1985. Competitive advantage: Creating and sustaining superior performance. New York: Free Press Collier Macmillan.

Porter, M.E. \& Kramer, M.R. 2006, 'Strategy and society: The link between competitive advantage and corporate social responsibility", Harvard Business Review, 84(12):7892.

Porter, M.E. \& Kramer, M.R. 2011. 'Creating shared value", Harvard Business Review, 89(1/2): 62-77.

Prahalad, C.K. \& Hamel, G. 1990. 'The core competence of the corporation', Harvard Business Review, 33: 79-91.

Rogers, E. 1983. Diffusion of innovations. New York: The Free Press.

Rousseau, D. M. 1995. Psychological contract in organizations: Undersianding written and unwritten agreements. Newbury Park, CA: Sage Publications.

Sanders, N., Locke, A., Moore, C. \& Autry, C. 2007. 'A multidimensional framework for understanding outsourcing arrangements', Journal of Supply Chain Management, $43(4) ; 3-15$.

Saxena, K. \& Bharadwaj, S. 2009. 'Managing business processes through outsourcing: A strategic partnership perspective", Business Process Management Journal, 15(5): $687-715$.

Seidler, J. 1974. 'On using informants: A technique for collecting quantitative data and controlling for measurement error in organizational analysis', American Sociological Review, 39: 816-831.

Sen, F. \& Shiel, M. 2006. 'From business process outsourcing to knowledge process outsourcing: Some issues', Human Systems Management, 25;145-155.

Sharma, A. 1997. 'Professional as agent: Knowledge asymmetry in agency exchange', Academy of Management Review, 22(3): 758-798.

South Africa the good news, 2013. 'SA wins offshoring destination of the year award'. [online] URL: http://Www.sagoodnews.co.za/private_sector_business/sa_w ins_offshoring_destination_of the year_award_2013.html.

Vashistha, A. \& Vashistha, A. 2006. The offshore nation. New York: McGraw-Hill.

Viviers, S. \& Eccles, N. 2012. '35 Years of socially responsible investing research: General trends over time', South African Journal of Business Management, 43(4): 116.

Williamson, O. 1975. Markets and hierarchies: Analysis and antitrust implications: A study in the economics of internal organization. New York: The Free Press.

Williamson, O. 1991. 'Comparative economic organization: The analysis of discrete structural alternatives', Administrative Science Quarterly, 36(2): 269-296.

Williamson, O. 1996. The mechanisms of governance. Oxford: Oxford University Press.

Wüllenweber, K., Beimborn, D., Weitzel, T. \& König, W. 2008. 'The impact of process standardization on business process outsourcing success', Information Systems Frontiers, 10(2): 210-224.

Yin, R. 2003. Case study research: Design and methods. 3rd Edition. Thousand Oaks: Sage Publications. 